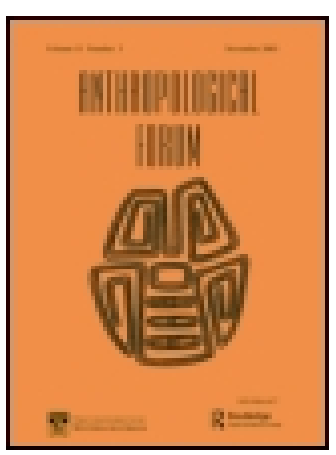

Anthropological Forum

A Journal of Social Anthropology and Comparative Sociology

ISSN: 0066-4677 (Print) 1469-2902 (Online) Journal homepage: http://www.tandfonline.com/loi/canf20

\title{
Special Module: Plenary Debate from the IUAES World Congress 2013: Evolving Humanity, Emerging Worlds, 5-10 August 2013
}

\section{Simone Abram, Greg Acciaioli, Amita Baviskar, Helen Kopnina, Don Nonini \& Veronica Strang}

To cite this article: Simone Abram, Greg Acciaioli, Amita Baviskar, Helen Kopnina, Don Nonini \& Veronica Strang (2016): Special Module: Plenary Debate from the IUAES World Congress 2013: Evolving Humanity, Emerging Worlds, 5-10 August 2013, Anthropological Forum, DOI: $\underline{10.1080 / 00664677.2015 .1102229}$

To link to this article: http://dx.doi.org/10.1080/00664677.2015.1102229

曲 Published online: 14 Jan 2016.

Submit your article to this journal $₫$

Ш Article views: 8

Q View related articles $₫$

View Crossmark data $\nearrow$ 


\title{
Special Module: Plenary Debate from the IUAES World Congress 2013: Evolving Humanity, Emerging Worlds, 5-10 August 2013
}

\author{
Editors: Simone Abram and Greg Acciaioli
}

Speakers: Amita Baviskar, Helen Kopnina, Don Nonini, Veronica Strang.

\begin{abstract}
This module for Involving Anthropology presents an account of one of the plenary debates held at the International Union of Anthropological and Ethnological Sciences (IUAES) World Congress held at Manchester University, 5-10 August 2013. The module begins with a brief introduction to provide the context for the debate, which included two speakers for (Amita Baviskar and Don Nonini) and two speakers against (Helen Kopnina and Veronica Strang) the motion: 'Justice for people must come before justice for the environment'. The introduction is followed by an edited transcript of John Gledhill's welcome and introduction, the texts of the arguments made by each speaker for and against the motion (with the exception of Veronica Strang, whose presentation is being published elsewhere a summary of the comments and questions subsequently invited from the floor of the hall, and then a transcript of the responses of the presenters.
\end{abstract}

\section{KEYWORDS}

Environment; justice; conservation; colonial policy; bio-centrism; human exceptionalism; nature; industrial capitalism; racism

\section{Introduction: 'Justice for People Must Come Before Justice for the Environment'}

Simone Abram

Department of Anthropology, Durham University.

The IUAES World Congress 2013 was held at Manchester University, 5-10 August 2013. The International Union of Anthropological and Ethnological Sciences (IUAES) (http:// www.iuaes.org/), as its name suggests, brings together scholars from all regions of the world and all fields of anthropology (Nas, Zhang, and Ji 2009). Every five years it holds a World Congress, with inter-congresses held in the intervening years. One of the features of the IUAES is that it can be seen as a counterweight to the predominance of AngloAmerican conferences, attracting significant participation from Asia, South East Asia in 
particular, and South America. Previous world congresses have been held in Russia, Mexico, Japan, India and China, as well as in European and North American cities. The World Congress in Manchester attracted a significant participation from Asia, notably India and Japan (where the subsequent Intercongress was held in 2014). Despite some very problematic obstacles, notably the unwillingness of the UK Border Agency to grant visas to visiting academics from several countries, there was broadranging participation in the Manchester congress.

Given the cross-field interests in the IUAES, the organising committee of the Manchester World Congress was keen to promote opportunities for discussion between different anthropological fields, as well as within them. At the same time, a key goal was to promote the kinds of important questions on which anthropologists are in a position to comment, to encourage British media attention, as well as generating participation in the congress. One way to achieve both goals was to organise plenaries in the form of debates, a form that is well established at Manchester University's Anthropology department (via GDAT, the Group for Debates in Anthropological Theory ${ }^{1}$ ). In organising the debates, the committee was attentive to the nationality, gender, anthropological field and ethnographic specialities of the speakers.

Three debates were held in the plenary hall. The second of these explicitly intended to generate discussion on one of the primary political issues of our day, the question of environmental justice. At a time when global talks were pitting economic benefits against climate risks, the question of justice was one the organisers wished to see from different perspectives. The second of the three plenary debates addressed the motion: 'Justice for people must come before justice for the environment'. Amita Baviskar (Delhi University) proposed the motion, seconded by Don Nonini (University of North Carolina at Chapel Hill). Helen Kopnina (The Hague University of Applied Science) opposed the motion, seconded by Veronica Strang (Durham University). The debate was chaired by John Gledhill (Manchester University).

The format of the debate pitches two pairs of speakers to argue for and against the motion, in turn. Members of the audience are then invited to pose questions to the speakers, and each speaker, again in turn, then presents concluding comments in the light of the questions and the other speakers' contributions. After all of the concluding comments, the audience members are invited to vote either for or against the motion. It should be noted that in devising the motion itself, the organisers sought to give the speakers an opportunity to fill out the arguments, raise issues related to the main theme, and explore the nuances toward which the motion pointed. The debate, with its parliamentary format, is one that offers an opportunity to elaborate on theoretical and practical implications of the motion. In the context of the Congress, there were no material consequences to consider (i.e. the outcome of the vote has no implementation in policy or practice), but the debate is a vehicle to elaborate key topics in a way that might appeal to a broad audience.

We present here John Gledhill's introduction, the texts of the arguments made by each speaker for and against the motion (with the exception of Veronica Strang, whose presentation has been published elsewhere-see Strang 2016). We then include a summary of the comments and questions subsequently invited from the floor of the hall, and then a transcript of the responses of the presenters. The debate was funded by the University of Manchester's Hallsworth Conference Fund. 
A live stream of the debate can be found here: http://www.youtube.com/watch?v= oldnYTYMx-k

\section{'Justice for People Must Come Before Justice for the Environment'}

JOHN GLEDHILL: The motion we're going to debate this morning is 'Justice for people must come before justice for the environment'. It is intended to be provocative, and if you don't like the motion, don't blame the speakers, because I'm afraid it was mostly-it was mainly - my idea. Usually, I have input from my accomplices in the National Organising Committee, but this was basically my concept of how to debate it, and the idea is that this debate is a complement to producing the Earth Track of the congress theme, so it combines political ecology and political economy.

The sponsor of the debate is the University of Manchester's Hallsworth Conference Fund. The Hallsworth bequests funds for postdoctoral research fellowships and visiting professorships, but the common denominator of all Hallsworth-funded initiatives is that they deal with political economy in the broadest possible sense, and this isn't actually the first time we've had a Hallsworth debate that tackles economic and environmentalist issues together in the same frame.

Now, as most of you are probably already aware, but I have to repeat it, the debate is organised in the following way: each of the four main speakers will speak for fifteen minutes at the beginning and then I'll open the discussion up to contributions from the floor, for which we should have about 30 minutes. Then I'll invite each of the original speakers to sum up or comment on what has been said for five minutes again at the end.

I just want to present the speakers very briefly. Amita Baviskar from the Institute of Economic Growth at Delhi University is going to speak first in favour of the motion, and Amita has made many important contributions to the study of the cultural politics of the environment and development from a perspective that brings questions of social inequality and power relations in natural resource conflicts, environmental movements, into very close focus. Her perspective also includes different social classes, social movements with different kind of class bases and ethnic bases.

Helen Kopnina from The Hague University of Applied Sciences in the Netherlands will speak second against the motion. Helen's work is strongly focused on the areas of conservation, sustainability and environmental anthropology, and she has published some powerful critical interventions in favour of reducing the androcentrism of much of the contemporary debate, and about taking the rights of non-human species seriously.

Donald Nonini from the University of North Carolina at Chapel Hill is going to speak third, again in favour of the motion. Don works on both the Southern United States and East Asia. His work is very wide ranging and includes critical theoretical contributions to the cultural politics of class, ethnicity, race, and gender in different kinds of settings, and the study of global and trans-national processes and the anthropology of the state. His approach to political economy in the case of Chinese developments has alerted us to the fact that it's perhaps not very wise to see the whole world as a replication of the neoliberal capitalism of the North Atlantic countries. 
The final speaker against the motion is Veronica Strang of the University of Durham and the new chair of the Association of Social Anthropologists. Veronica's research is focused on human-environmental relations from a perspective that explores the cultural dimensions of the ways in which people engage with resources. Her recent works focus on what must be one of the most critical issues facing the world today: the question of water. She takes a cultural perspective on the way people think about issues of water, conservation and the symbolic meanings that are attached to water as a vital resource in different kinds of cultural contexts.

So that's our lineup; I'm looking forward very much to listening to them ... Okay, let's begin.

\section{For the Motion: Amita Baviskar}

Between 1868 and 1888, the British government drove out the Baiga, a tribe of shifting cultivators in central India, from the forests that they had lived in for generations and herded them onto a reservation. Here, they were forced to settle down and take up farming with ploughs. The Baiga believed that to plough the land was to wound mother earth, a violation of their most sacred principle, a betrayal of what it meant to be Baiga. Forced into an alien occupation, the Baiga suffered what Verrier Elwin ([1939] 2007) described as 'a loss of nerve' - a profound and debilitating erosion of morale. From being shamans and healers, a tribe with knowledge and power, the Baiga became a broken people, joining the ranks of the wretched of the earth. It took more than 40 years for another generation of Baiga to rise up in rebellion against colonial forest policies and demand the right to cultivate freely once again.

The displacement and dispossession of the Baiga contain echoes of events that took place in other parts of the colonial world, including Britain. The woods and pastures of England had already been placed off-limits by private landowners between 1760 and 1820, impoverishing subsistence farmers who depended on them for their fuel, fodder, and other modest needs. Karl Polanyi (1944) called this enclosure of the commons 'a revolution of the rich against the poor', a revolution where the armed might of the law, the repressive power of capital punishment, prison and deportment, was wielded as a weapon to commit what E. P. Thompson (1975) called 'a plain enough case of class robbery'. Though poor and desperate peasants fought fiercely to hold on to the ancient customary rights that they valued, they were dispossessed. In Africa and Asia and Australia, as in Americas, colonial conquest meant that land was acquired by force, native populations decimated and subjugated, in order to make resources available to the imperial enterprise.

But the displacement of the Baiga was not justified as brute force-the power of the conqueror to call the shots, to plunder and possess at will. The colonial government took pains to explain that the Baiga practice of shifting cultivation was environmentally harmful. It was in order to protect the forests, to better conserve them, that the Baiga had to be confined to a reservation. The Baiga, who had lived in the forests for centuries without noticeably depleting them, were now blamed as destroyers of the forest, a problem for the new regime of 'scientific forestry', the technique of replacing diverse tropical forests with simplified monocultures of teak and sandalwood that fetched the highest revenue. Dietrich Brandis, the first Inspector General of Forests in India, institutionalised a calculus 
for maximising timber growth, with all other living aspects of the forest seen as unimportant, at best, and problematic, at worst. With the authority of German forestry experts backing colonial ideas of 'environmental protection', the displacement of the Baiga became a 'scientific solution'. It was, in fact, argued that their transformation into farmers with settled, steady habits would be morally and economically good for them.

Now this is the point that I want to stress: the colonial government believed that it was doing the right thing. As Richard Drayton pointed out in his book Nature's Government, (2000), the idea that Empire was about improvement, husbanding resources, controlling lands and peoples for the purpose of conservation, better management for more efficient utilisation, was an intrinsic part of colonial enterprise. Empire was justified as an instrument of development, of 'fostering and leading new races of subjects and allies in the career of improvement' (Drayton 2000, 94). Managing places and people for their material and moral upliftment, the paternalistic presumption of 'allow us to know you better than yourself, was the conceit that colonialism maintained even as it wreaked havoc on landscapes and lives around the world. This paternalistic condescension continues to pervade most Northern campaigns for saving the planet.

In east Africa, too, environmental conservation was a coercive business, with customary hunting and grazing practices forcibly curtailed by the colonial government. Rod Neumann (2001) points out the injustice that, even after independence, local populations in Tanzania and Kenya still don't have control over vast tracts of land. And while they are forbidden to hunt for meat or even to kill predators that menace their livestock, wealthy tourists from the West are licensed to kill animals as trophies on privately managed reserves. Double standards and doublespeak have been remarkably consistent features of saving the environment. Lending legitimacy to such ploys is the narrative of environmental crisis, of catastrophic consequences if the population explodes, if the rains fail, if we run out of food or oil, if the oceans rise. Without dismissing or diminishing the real and serious challenges that these pose, one must wonder how the urgent goal of saving the earth invariably translates into business-as-usual, with the usual suspectsinternational conservation organisations funded by corporate donors, governments backed by national elites, the World Bank and the ADB-providing all the answers on behalf of the Global North.

If utilitarian ideas of protecting the environment for the greater glory of empire or capitalism or the nation have dispossessed people and destroyed culturally distinct ways of living with nature, poor people today have another, even heavier, burden to bear. This is the so-called biocentric view which claims that all forms of life have a right to exist, and that environmental conservation is a transcendental goal, one that must rise above the petty squabbling of social groups about who bears the costs of conservation. Justice for the environment means respecting the rights of all species, not just humans. Now this is a noble sentiment, but logically specious. What do they mean when they want to respect the rights of all species? Do they believe that the smallpox and polio virus have as much right to exist as the tiger and the blue whale? How about the AIDS virus or Plasmodium falciparum? Humans make choices about species all the time: this is a good plant to grow; this is a weed, let's pull it out. These choices have shifted with time: for instance, in India, leopards and tigers have gone from being vermin to being trophy animals to nationally protected species within a space of a hundred years. These shifts reflect the varying cultural perspectives through which nature is everywhere 
evaluated. The environmental good is a moving target, a fact that should make one question even more closely the sacrifices that poor people are asked to make for it.

Biocentrism is not a soft-hearted romantic view of respecting the earth. As Ram Guha (1989) points out, if you look at who its proponents are and what they actually do, you will find a pernicious exercise of Northern privilege. Speaking on behalf of those voiceless species, Northern biocentrism has supported the creation of large conservation areas, driving out forest dwellers and extinguishing their rights to subsistence. An even larger, even obscene, injustice is that even as they expect the Global South to give up the little that it has, the bio-centrics choose to ignore the inequities in which they themselves are complicit. As citizens and beneficiaries of the military-industrial complex, as consumers whose endless appetites scoop up resources from around the world, those who claim to speak for the planet and tell people in the Global South how they should run their lives, are guilty of forgetting the first law of biocentrism: All life is connected.

In addition to the presumption that those who claim to speak for the environment are somehow morally superior to those who represent forest dwellers, farmers and pastoralists, there is the assumption that an environmental goal is by definition a universal good and must prevail over the interests of particular social groups even if they are poor and exploited. In Delhi, where I live, the cause of creating a 'clean and green city' has been vigorously pursued by bourgeois environmentalists, who have used the Supreme Court and the High Court to get rid of thousands of small industries and hundreds of squatter settlements where working class families worked and lived. The instrument for this judicial action has been public interest litigation-on the grounds that securing clean air and water and green spaces is obviously in the public interest, the greater common good. However, the idea of the public is mobilised to exclude and disenfranchise large sections of the city's population. The courts and the media have consistently turned a blind eye to the devastating effects of such projects of urban improvement on the lives of Delhi's under-class. That the working poor may have their own environmental priorities, such as toilets and sewers and drinking water, is not even considered. Nor is the fact that the greater burden of air and water pollution in the city is generated by the rich, by their cars and their sewage. In the name of environmental improvement, we get more injustice-for people and, ironically, for the environment.

Protecting the environment, then, seems to be yet another scheme of organising the world, landscaping the globe into a mosaic of separate zones-extraction, production, consumption, conservation, and so on-designed by the Global North, where conservation may be another form of elite consumption, of controlling places and lives to feed Northern desires.

This seems all the more tragic when we think of all the ways in which communities have, in fact, cared for their environment, often under daunting odds. These examples of conservation seem like embattled islands in seas where the tide of extractive consumerism is always rising, never receding. In the Niyamgiri hills in Orissa, or in the Narmada Valley, people have come together to negotiate with the state on their own terms. They reject how environment and development are brandished as double-edged weapons: your land, forest and rivers for our money, roads, schools, medicine, our religion, our values. To speak for the rights of these communities is not to romanticise them as ecologically noble savages, as bearers of every environmental virtue, but to direct attention to the processes of capitalist extraction in which power and profit lie in the Global North. 
We need an honest discussion about contending modes of appropriating the environment, about property rights and planetary priorities: Environment for whom? Which people? Whose justice? Since the environment exists in culture, it is the cultural modes of producing and legitimising unequal rights to the environment that we must highlight and challenge.

\section{Against the Motion: Helen Kopnina}

I am going to argue against the motion 'Justice for people should come before justice for the environment'.

Having read some of my opponents' publications, I assume that Amita Baviskar and Don Nonini will support the idea that conservationists are mostly Western elites and that their actions impinge upon cultural practices and economic development of local communities. This argument is well developed in anthropology explicitly criticising conservation, where anthropological engagement is seen as a duty to uphold human rights and indigenous entitlements against Western neocolonialist practices or neoliberal capitalist conservation. This critique often involves a discussion of historical contexts in which conservation areas or national parks were created in developing countries, with particular emphasis on the critique of the top-down and neocolonial practices, in which environmental values are seen to be either imposed by post-colonial governments or by international conservation organisations.

So far, I agree with my opponents, as I too fully embrace and support the efforts of non-Western communities, minority groups, or marginalised societies in their efforts at cultural self-determination. In a similar way, the nuanced critiques of prominent anthropologists Dan Brockington, James Igoe, and Paige West show how large Western conservation organisations have become commercialised and profit-seeking themselves, and how native ways of being in the environment have been subjected to more managerial or prohibitive approaches in which the conservation organisations profit, while the local communities are left displaced and without compensation (West, Igoe, and Brockington 2006; Igoe and Brockington 2007; Brockington, Duffy, and Igoe 2008). Environmentalism or conservation in this context becomes suspect due to its proximity to the capitalist rapacious, neo-imperialist and even racist enterprise which tends to perpetuate environmental injustice through impingement on human or indigenous rights, while catering to wealthy elites.

In line with the critiques of the neocolonial Western enterprise, I do believe that industrial development-both in socialist and capitalist societies-has ultimately led to the erosion of cultural diversity and to creation of unwieldy development projects that tended to enhance, rather than address, current social and economic inequalities. I also agree that environmental justice, meaning the equitable distribution of environmental risks (such as pollution) and benefits (such as access to natural resources or conservation benefits), remains a large global challenge.

Yet, there is part of this critique that I think needs to be examined more closely. In this well-established critique of neocolonial neoliberal enterprise, the question of ecological justice, or justice between species, is often completely overlooked. Anthropologists such as Rosalyn Duffy and Robert Fletcher argue that conservationists impinge upon cultural practices and economic development of local communities in order to create conservation 
areas and preserve biodiversity. Some engaged critics actually argue that 'it is ethically problematic to privilege conservation of a maximum level of biodiversity at the expense of livelihood security and poverty alleviation' (Benjaminsen et al. 2006). The well-known anthropologist Conrad Kottak suggests that it is an anthropological moral duty to prioritise people's interests and 'not be dazzled by ecological data' (Kottak 1999, 33). It is this particular ethical position that people should always come first and the rest should be ignored, as it deserves no moral consideration, to which I would like to object.

Another issue is that environmentalism is not a Western but a universal phenomenon, and that love of nature is shared by traditional societies. In fact, it was traditional societies prior to colonialism and prior to economic development that were more naturally interconnected to the greater than human world. At present, however, despite recognition of the fact that that indigenous people are 'rarely isolated from global market forces' (Pountney 2012, 215), anthropologists who defend the 'people should come first' notion seem to somehow simultaneously assume that some cultures or societies are still 'traditional' and thus reify cultural traditions (implying somehow that some people are really more 'developed' than others) and try to defend the disadvantaged communities' economic rights (which are anything but 'traditional'). By talking about natural resources, economic benefits and compensation, supporters of 'humans first' perspectives also tend to think of these simultaneous traditional/cultural and modern/economic attributes not only as entitlements, but also as morally normative categories. Within these categories, ethical considerations often automatically weigh toward 'disadvantaged' people and not disadvantaged non-human species.

The counterargument I want to develop here is best summed up in the words of environmental sociologist Eileen Crist, who simply indicates that what is presently happening is a great moral wrong of which we are simply not aware: 'The mass violence against and extermination of nonhuman nations, negating not only their own existence but also their roles in Life's interconnected nexus and their future evolutionary unfolding' (Crist 2012). In her poignant essay 'Requiem for a Roadkill', anthropologist Jane Desmond (2013) calls for an ethical recognition of animal victimhood. Another anthropologist, Barabara Noske (1989), has called for anthropologists to heed environmental ethics. In environmental ethics, the definition of land ethics comes to mind: '[a] thing is right when it tends to preserve the integrity, stability, and beauty of the biotic community. It is wrong when it tends otherwise' (Leopold [1949] 1987, 224-225). Similar to the land ethics, the deep ecology movement endorses 'biospheric egalitarianism' (Næss 1973), the view that all living things are alike in having value in their own right, independent of their usefulness to humans.

I feel that this debate is both extremely important and also extremely non-academic. It is moral, and it is political, and it is far from scientific. That is why I very much appreciate the fact that I was invited to be here. Returning to the original motion of this debate, please consider the following questions:

- Justice for people must come before justice for the environment?

- Justice for men must come before justice for women?

- Justice for Whites must come before justice for Blacks?

- Justice for heterosexuals must come before justice for homosexuals? 
How is this motion, that justice for people should come before the environment, different from the good old 'might makes right' assumptions? I would like to ask the audience some more questions:

- Are these questions appropriate for anthropology and anthropologists?

- Why is racism, sexism, and every form of human discrimination seen as 'bad' in anthropology and yet discrimination against other species is exempt from the moral sphere of judgment?

- Should engaged anthropology not include ecological, not just environmental justice?

- If ethics can be seen as 'progressive', should environmental rights not follow human rights, women's rights, minority rights, etc?

- Now when entire species are used for mass production and consumption, or critically endangered or at the brink of extinction, is it not time to acknowledge environmental rights?

- What is the basis of moral judgment that makes one species-not just the rich and the poor, the white or the brown within the species-so far superior and worthy of moral consideration than all the millions of the earth's other living beings?

I agree with the proponents of the motion that culpability for ecological problems lies largely with corporate and political elites that perpetuate the industrial economy, mass consumption and commodification of nature. Yet, I disagree that environmentalism is western, elitist, and neocolonial. Environmentalism, and the love of nature, belongs to all people. As Shiva (2012), has said: 'When nature is a teacher, we co-create with her -we recognise her agency and her rights'. I also do not doubt that without environmentalist activists, the very power hegemonies that all of us criticise will continue unabated, erasing cultural memory that used to foster sustainability and preserve ecological knowledge. What seems neocolonial to me is not conservation or environmentalism, but the insistence that we should look at everything in monetary terms, that we should abandon nature, or rather use it as a natural resource for our enrichment, that we are above nature, and that all that matters is how equitably the bits and pieces of wilderness that remain are divided between human populations. This thinking is in no way 'traditional', but reflective of what proponents of economic development would like us to embrace.

Privileging one species over all others tends to render the world as perhaps the same as what very corporate, political, profit-driven elites would like to see-productive, efficient, devoid of emotions, consciences and beauty. Yet, we are all intertwined, all affected. After all, environmental degradation affects us all, either through climate change or pollution, or through the erasure of biocultural diversity. As Siddharth Chakravarty, a First Officer on the Sea Shepherd vessel renamed Steve Irwin, has said, 'It is important to preserve the biodiversity of the planet. If the oceans die, we die.'

Presently, we ask: What is the maximal number of people for which the Earth can provide resources without severely degrading those resources for future human (sic!) generations? How can environmental justice (equality in distribution of environmental risks and benefits) serve all human beings? Yet, what about those 'others' that are driven to extinction, turned into 'roadkill', relegated to the beyond-moral-consideration realm of 
collateral damage when huge areas of the rainforest are cleared for cultivation. Can we still speak about Justice?

Should we not ask instead, returning to Crist (2012): How many people, and at what level of consumption, can live on the Earth without turning the Earth into a human colony founded on the genocide of its non-human indigenes? The latter is rarely posed because the genocide of non-humans is something about which the mainstream culture observes silence. Academics largely follow suit, perhaps because they view raising an issue about which silence is observed as a non sequitur (Crist 2012). Thus, I disagree that we should stop at environmental justice defined by social equity and economic redistribution only. Injustice affects some more than others, and this effect goes beyond the questions of economic benefits and cultural determination. It effects the very survival of numerous living beings.

Considering the fact that continuous advocacy and representation are needed to represent non-humans (who will never speak for themselves), we need to push the ecological justice debate beyond academic compounds. This might require much more affirmative action'. This implies the need to develop a post-racial, post-gender, post-class, undifferentiated humanity so we can develop responsibility for other species. If social altruism can be learned (assuming that acquisition of ethical values is socially and culturally conditioned) or morally developed (assuming that there is such a thing as moral progress), this has significant implications for fostering biospherical egalitarianism and supporting biocultural diversity.

Finally, I would like to leave you with the story of Ganesha and the cat.

As a child, Ganesha loved playing with his bows and arrows. Spotting a white cat one day, he decided to play hunter and shot arrows at it. The terrified creature ran for cover, but Ganesha thought it was playing a game.

He looked behind a tree - there it was, trembling and round-eyed. 'Aha, got you!' said the chubby god and shot at it again. Miaowing with fear, the cat scooted for cover under a log. Ganesha chased it down and pulled it out. He rolled it around in the mud and threw it up in the air like a furry ball! Once more, the cat escaped. Ganesha lost interest and went back home.

He was in for a shock. There sat Parvati, his lovely mother, her face and arms scratched and mud-stained.

'Ma, how did you get hurt?' cried the little fellow.

'I've no idea,' said Parvati. 'What have you been up to?'

'I was playing with a cat and... um... I was pretty rough with her.'

'Now I know why I have these bruises!' said Parvati. Drawing Ganesha close, she explained, 'Ganesha, my body is the world and every living creature in it. I was that cat, too! Whatever you do to other beings, you do to me as well!'

Ganesha was stunned and deeply remorseful. 'So my every little action matters... wow! I'm so sorry, Ma. I'll never do harm to anything... ever!'

Smiling at her son, Parvati said, 'That may not be possible, son. But do be aware of your actions and harm as little as possible.'

Nodding, Ganesha ran off to find the little cat and make peace with her.

In my last slide, you can see the picture of my three kids that I left in Colorado during the holiday to come here. I came here because I think that their future-and the future of billions of other children, kittens, and cubs depends on whether we take a firm ethical and political stand, within and beyond academia.

I ask you to vote against the motion. 


\section{Seconding the motion: Don Nonini}

In this debate, I second this motion. My argument will briefly proceed as follows.

\section{Philosophical argument against the opponents to the motion}

First, I will argue that it is inconsistent and fallacious to argue for justice for the environment as distinct from justice for people who are organically part of an environment. The opponents to this motion are caught on the horns of an intractable dilemma. Either they must argue that humans are not part of the environment, or they must argue that humans are part of the environment, but should be an inconsequential element within that environment, somehow subtractable from it in such a way that what is non-human, thus purified of the human, can be said to be the environment for which justice can be posited.

If the opponents to the motion adopt the position that humans are not part of the environment, then they have made an assumption that is empirically incorrect. It is manifestly the case that human beings are one species that participate actively in networks of metabolic interactions with other species. Human beings depend upon other species for digestion, respiration, waste disposal, shelter, protection, etc., and the other necessities of human life. In turn, humans also have acted, not always under specific conditions of their choice, as stewards for the reproduction and continuity of survival of non-human species. They voluntarily promote the survival of species (and networks of species) which they domesticate, cultivate, and protect from incursions by other humans or by non-human species; they involuntarily serve as food and as environments themselves (e.g. in the case of the thousands of species of bacteria that are part of the human micro-biotic environment), as reservoir (e.g. for parasites during part of these species' reproductive cycles), etc. To engage in the pretence that human beings are not part of the environment in this sense is to engage in a kind of counterfactual fantasy that should be easily dismissed.

If, on the other hand, the opponents to this motion argue that humans, although part of the environment, should be relegated to a much more inconsequential part of that environment, such that their welfare can and should be subtracted out from that of the non-human elements (both living and nonliving matter) of the environment, then what? The idea is that humans should just go away; that apparently it would've been much better for the purposes of justice if they had never existed to begin with. This, one can demonstrate, is the foundational assumption behind most forms of Malthusianism. In this case, however, not only do the opponents of this motion engage in an antisocial, indeed anti-human argument, but they do so on flimsy philosophical grounds.

Here our opponents find themselves caught on the horns of another intractable dilemma. Either they ask the same humans to legislate their own non-presence in the environment, since it is only humans who can seek and obtain justice-not other living or nonliving forms of matter-but this would require the self-annihilation, or at least self-dispossession, of humans who would extract themselves from 'the environment'. Now, I would argue this is empirically extremely unlikely, and morally repugnant! The other horn of the dilemma would have to be that justice for the environment in this case requires that some humans legislate, in the interest of justice, that other humans 
who are part of specific environments other than the environment of such legislators be removed from these other environments in order to be more just to the non-human elements of those environments that remain. This second horn of the dilemma, I would argue, is precisely what the opponents to this motion would have to favour, but this conception of justice presupposes processes of violent dispossession which have historically been associated with imperialism and the triumph of supposed 'civilisation' over those who are 'primitive', etc. One might take, for example, the numerous opportunities that European colonial administrators in South East Asia employed to 'prove' that swidden cultivation by indigenous peoples was necessarily 'wasteful' and 'inefficient,' thus demanding their removal from such lands in the interest of 'the Crown' and similar imperial entities. In other words, this is where the 'rubber hits the road, or tarmac,' where a broad principle that humans ought to be extracted from the environment they depend upon in order to save it, improve it, protect it, etc., is distilled down to, and hypostasised into, the ugly facts of colonialism and imperialism, of 'native removal', ethnic cleansing, and the like.

\section{The Substantive Case for the Motion}

It is time to move beyond such logical difficulties for our opponents to state the positive case for our motion-that justice for people must come before justice for the environment. To begin with, it is necessary to examine the intertwined facts of history and nature that were (in my opinion) incorrectly opposed in the prior debate of Monday. In other words, to start with, instead of speaking of 'the environment,' let me instead speak of nature, and the role of history in its making.

'Nature' in the sense that we have to use it today is one based on 'second nature'-the conception by Marx and Engels that nature under capitalism is nature transformed fundamentally by human activity. In contrast, as Marx and Engels put it in The German Ideology, 'Nature, the nature that preceded human history ... is a nature that no longer exists anywhere (except perhaps on a few Australian coral islands of recent origin)' (Marx and Engels 1973, 63). In other words, neither nature nor the environment as they are constituted remain unmarked or untransformed by human activity. While our opponents will concede that this is so-because it is presumably the source of their complaint that there is insufficient justice 'for the environment'-it has implications to which they have not sufficiently paid attention.

The principal issue that our opponents have neglected is that if nature is indeed second nature transformed by human activity and practice, then justice for nature or the environment is inextricably connected to justice for human beings - that is, justice toward human beings in the process of their transformation of nature. And, following the premises of Marx and many subsequent thinkers within political economy, justice toward human beings in their transformation of nature is necessarily justice in their relationships to one another. This is now what we need to consider.

However, what are these injuries to the environment that our opponents (and indeed we ourselves) see requiring redress? What are the elements of the 'planetary ecological crisis'? These would include within the period of last 300 years of industrial capitalism: the signs of global climate change (the melting of the Arctic and Antarctic ice sheets, a rise in sea level, rapid decrease in glaciers, ocean warming and a consequent dramatic decrease in oceanic phytoplankton, droughts over wide areas, and extreme weather events). But beyond local 
climate change, we can refer to ocean acidification, the extraordinary burden of nitrogen and phosphorus runoff into the fresh and salt waters of the earth, the disappearance of fresh water due to disruptions in planetary hydrological cycles, deforestation, and atmospheric loading with toxins, in addition to emissions of carbon dioxide that are the principal source of global warming. All these changes represent profound harm to nature and the environment, characterised most dramatically in the extraordinary loss of animal and plant species in what paleontologists are now calling the 'sixth great extinction'. Any sense of justice to which most humans would hold in the face of these transformations would seek to redress and even reverse these transformations in order to seek the best possible remaining prospects for the survival and enhancement of humans and other lifeforms on earth.

Here's what it comes down to. I wish to simply observe that by far the most crucial determining factor, as well as the most deleterious force, with respect to these major transformations in the planet's ecologies has been the actions of, first, modern colonial and, now, transnational industrial capitalisms and their compliant nation-states. Over the last two centuries, starting with but not limited to Western modernity (because of the complete complicity of Asian capitalisms in these transformations), these actions have led to the massive exploitation/extraction of natural resources, including non-human biota and flora, and the reorganisation of their production and extraction by industrial means.

If we but note the effects of industrialised agriculture, in which food is produced with industrial methods in massive, simplified monocropped plantation ecologies, processed in energy-intensive ways, transported over thousands of miles, and marketed to wealthy 'consumers', all to further the expanded capital accumulation of a few number of transnational food processors, traders, and retailers, then we can quickly see how central and deeply implicated are the indeterminately expansive logics of corporate capitalism in these harmful transformations of planetary ecologies. Industrialised agriculture, however, has also reduced hundreds of thousands of people to no more than the 'backs' and 'arms' of proletarianised farm labour that these corporations require.

But we could also give innumerable other examples from extractive capitalism of how injustices to people are linked to injuries to natural ecologies-whether it is despoliation of land and freshwater for farmers by the corporate copper and nickel mines in the Andes, or of the deltaic, littoral, and oceanic ecologies of the Gulf region of North America, which has ruined the livelihoods of fishers brought about by the massive BP oil spill. And in the most recent form, the dominance of financial capital, we can speak of massive 'land grabs' in Africa, Latin America and elsewhere, the 'financialisation of nature', and of speculative finance in the ongoing commodification of hundreds of thousands of numerous forms of goods previously held in common by humans-and of the displacement of prior occupants of land and users of resources.

Now having stated as much, it is also straightforward to observe that the expansion of industrial and financial capitalism across the planet over the last three centuries has been the major, if not the only, source of injustice toward human beings. This is at no time more obvious than in the current period of neoliberal capitalism, in which, as David Harvey and numerous other commentators have demonstrated, millions of people are experiencing accumulation by dispossession, intrinsically in the course of capitalist expansion and the environmental transformation of nature it has entailed. However, accumulation by dispossession has been a recurrent feature of modern capitalism over the last several centuries. 
Whereas today millions of farmers are forced off land to install hydroelectric projects in the Middle Yangzi River to promote China's capitalist industrialisation, three decades previously millions were forced from their lands by the hydroelectric and other massive development projects of the World Bank. We are talking of nothing less than what Horkheimer and Adorno in Dialectic of Enlightenment (1972) called the 'instrumental domination of nature' associated with capitalist expansion and accumulation on a world scale.

What we are therefore arguing is that appropriation of nature via capitalist industrial means and the grossest and most abusive exploitation of human beings have necessarily gone together. Since we are referring to both human beings-qua exploited surplus and displaced labour-and the 'environment' or nature as what is being depleted, ruined, etc., it is important to realise that the processes of capitalist appropriation and realisation of surplus value and of environmental degradation/simplification have always gone together. Coal mining corporations in West Virginia in the US not only degrade the environment through 'mountain top removal', but also degrade the lives and living conditions of human beings - not only those who are employed by these corporations (who experience multiple occupational injuries such as black lung disease), but also those people living in the 'environment' of the mines. ${ }^{2}$

\section{Summation}

Here is the concluding gist of my argument, in the form of several modest proposals.

1. Coincidence. If the causes of injustice to people and of injustices to nature are so closely intertwined, so too must be justice toward people and toward nature. Our motion states: 'Justice toward people must come before justice toward the environment' - not that there is to be no justice for the environment. Contemporary corporate capitalism is engaged simultaneously in carrying out multiple forms of injustice directed toward millions of people by disrupting and destroying their livelihoods, even as it is also engaged in perpetrating multiple injuries to environmental ecologies and the material (bio-chemical) infrastructures and processes that make these ecologies possible.

2. Mutual Implication. It is abundantly clear by now that these insults toward the environment also imply injuries and abuses of human beings, because the former have adverse impacts on human livelihood and survival even in the middle termthat is indeed what global climate change and the other dimensions of the planetary ecological crisis imply.

3. Prior Qualification. Abused and exploited humans are in no position to remediate environmental injuries; dispossessed, the victims of the structural violence of capitalism, they lack the surplus capacity and political power to redress these injuries. Only flourishing humans are in a position to make such changes.

4. Multiplicity of Struggles. Therefore, the only justice possible for the environment requires concomitant or prior justice for human beings, and that form of justice in today's world must come out of multiple struggles, in many different locales, on many different fronts, against the abuses associated with transnational corporate capitalism-its mistreatment of human beings in the name of capital accumulation, but also its degrading transformations of nature in accordance with its indeterminately expansive logics on a finite planet. 
5. The Only Possible Prospect. Justice and morality are distinctively human. 'Justice' depends upon moral values and practices, and ultimately on moral action. But human beings are necessarily motivated by questions of their own survival, and the majority of human beings alive today are necessarily so motivated, even as they are subject to the oppressive conditions of capitalist power. The fundamental question is how to transform such motivations toward human flourishing to include the flourishing of nature (biodiversity, etc.) on which humans depend, and to mobilise both into specific forms of struggle against capitalist injustice. This is the only prospect before us, since nature divorced from humans cannot seek justice. Therefore not only in the ethical sense, but also in the pragmatic issue of 'What is to be done?', the answer can only be: 'Justice for human beings must come before justice for the environment.'

See Strang (2016) for the text of her contribution to the debate.

\section{Summary of Questions and Comments from the Audience}

(NB: During the discussion, no speakers identified themselves by name. It is possible to watch the debate online, at the URL noted above).

The discussion began with a suggestion that each of the presentations had argued in a similar vein, that justice for people must come with justice for the environment-a theme that then ran throughout the discussion (along with appreciation of the speakers' presentations). There was general agreement that in Anthropology, there is a broad awareness that the dichotomy between people and the environment is historically situated, and that there are many people in the world who are committed to the interconnectedness of things and beings (an example was offered of Zuni people endowing things with personhood). One contributor observed that the human body itself consists of more cells that are non-human than human, reinforcing the illusory quality of the dichotomy between the human and non-human.

Two key issues were raised in relation to the opposition between environment and people. The first related to the hierarchy of justice implied by the motion. Transposed to a set of questions about whether justice for men should precede justice for women, it is apparent that the grammatical structure creates a false equivalent, which requires an entity named the environment to be anthropomorphised in order to allow it a place in this hierarchy. As such, it normalises the Western traditions of instrumental reason, rather than generating a more inclusive awareness of the human. It also presumes that the problem of justice for people has already been resolved, as though having addressed questions of gender or ethnicity, we might now turn to justice for animals and plants.

The second substantive point builds on this lack of progressive justice, in relation to the use of environmentalism (the prioritisation of justice for the environment) as a political tool of the privileged. There are numerous instances in the ethnographic literature of cases where conservation has been pursued at the cost of the most deprived people, where progressive inequality has been justified in the name of conservation. In a Latin American context, for example, it was claimed that environmentalism and conservation are political tools of the rich. Yet, environmentalism has also been exploited by indigenous and minority groups. Two examples were raised: first, the case of the Yanomamo leader who presented himself using shamanistic discourses to appeal to environmentalists in 
Brazil; second, the rubber tappers' leader in Brazil, Chico Mendes, who achieved international recognition by engaging with the environmental movement.

These examples also suggest that the term justice itself requires closer inspection, since much of the discussion appeared to be focused on distributional justice, while procedural and interactional justice may prompt a different dynamic between the environmental and the human (again illustrating the difficulty of leaving behind the dichotomy while analysing it). Contradictions between ethical claims to justice and legal definitions of justice would require further attention for the debate to progress. Questions might include whether non-humans should have rights, what those rights should be and how those rights should be balanced with the rights of humans, for example.

\section{Responses by the Debate Contributors}

AMITA BAVISKAR: Thank you for that amazing array of questions and comments. I don't think I can do justice to even the majority of them, but I'll try and weave some answers into what I'm going to say now. Let me begin by quoting Raymond Williams from his essay, 'Ideas of Nature'. 'The idea of nature contains, though often unnoticed, an extraordinary amount of human history' (Williams 1980, 67). He says, 'We've mixed our labour with the earth, our forces with its forces, too deeply to be able to draw back and separate either out' (Williams 1980, 83). But the idea of nature or the environment as a separate realm lying outside culture is still one of the chief organising fictions of contemporary conservation, and I think when some of you said:

We need to get away from this dichotomous formulation, this motion that justice of people must come before justice with the environment, and replace it with something that says, 'The justice for people must come along with justice for the environment'.

I think we're in a way trying to avoid a really difficult question, which is that we can never know what constitutes justice for the environment. Sure, strip mining is worse than swidden cultivation, but, as the example of flying told us, these choices are actually incredibly complicated. How do we know that protecting one species or protecting one ecosystem is more important than protecting others, especially when we've discussed the cost that these entail? So what we can know a little bit about-and I think that one certainty is something that we must hold on to as a precondition for a dialogue on conservation - is the idea of justice for people, because, when we're talking about people and the environment together, we can only talk about them in interrelated ways.

If there's one thing that anthropologists and ecologists agree on, it is an appreciation of diversity; it is an appreciation of the ways in which we can't talk about the environment or people in the abstract as homogenised entities, but we have to talk about particular groups of people, their specific characteristics as culturally bound, culturally shaped communities embedded in specific power-laden relations, as much as we have to talk about the specific forms that ecosystems and ecosystemic processes take. So when we begin with that idea of diversity and the appreciation of inequalities within that diversity, I think we have to say that recognising that diversity is something that can be discussed among people, is something that we can begin with, and it is only through people that we have access to the environments over which they claim to have multiple claims. So, both in terms of substantive as well as procedural justice, I think we have to begin with looking at different people, 
different stakeholders if you will, who lay claims to the environment, and we have to be able to negotiate those claims on terms of greater equality than is the case now. Ethical questions are always political questions; I can't distinguish between the two. So when we're talking about the issue of race or gender or caste or religion or nation, and the question, as Helen asked is, 'Why can't we apply these ideas and also talk about the environment question in the same way?', I'd say that all of these questions are asked with reference to specific populations. To which specific populations do we pose the environmental question? That is indeterminate in a way that isn't the case with gender or with particular claimants to religious or national or other identities. So, it's only when we can recognise the diversity of claims, their plurality in relation to the environment that we can talk about environmental rights as something which is equally contentious along with other kinds of identities. I think that's about all that I want to say.

I mean, I appreciate the point about the different ideological forms that environmentalism takes, from, progressive, socialist versions to fascist ones, and I agree that there are extremely sophisticated networks that bind people together in these circuits, in these increasingly transnational circuits of environmentalism, and, we just have to be attentive to the ways in which there are many frictions within these as well. You gave one example from the Amazon; I'd give another of the Rainforest Alliance and its support for the Kayapo whose leader was projected as, somebody who was the 'Spirit of The Rainforest' and who later, when the Kayapo did, in fact, gain control over their territories, went on to make deals with timber contractors. So, one can't take environmental virtue for granted. One can only see it as one more currency in a world where this certain form of Indigenous performers gets rewarded. In fact, one must never question the terms on which that discourse happens, where the Kayapo are incarcerated in the rainforest and forced to perform a certain kind of exotic notion of indigeneity for the consumption of their so-called supporters in the Global North. And, again, I want to highlight that I'm using the term 'Global North'; by no means do I want to suggest that it's the West versus the East. In my own country I belong to a class that certainly does claim to speak for the environment in terms of great nationalist fervour and that has been equally destructive of the rights of other people and other citizens of India and the world. Thank you.

HELEN KOPNINA: Well, a few points that I find common to our discussion, as well as one from the floor, [concern] the point of commodification of nature; I think we all agree, all four of us, that the rapacious capitalist enterprise tends to turn everything into marketable commodities, tends to value nature as natural resource, ecosystem services, whatever the popular World Bank or IMF terms are, and is largely responsible for global imbalances in social terms, as well as, ecological terms. I think what all of us are also addressing here is the idea that you have power relations in which, indeed, a large percentage of the communities-human communities, as well as non-human communities-are disadvantaged. My own ethnographic vignette-to add to what we've heard before-my own research is about environmental education and actually Western style of consumption; my recent articles address Dutch school children and Dutch business students' opinions about things like transportation use and consumption. It's remarkable coming from this Western world, indeed, how unsustainable our lifestyles are, and even despite the ecological modernisation theory or ecological Kuznets curve that at first you have some kind of 
accumulation of polluting, unsustainable practices and then they eventually lead to ecological, more green technologies, etcetera. Well, look around you in Manchester, look around you in whichever country you go to in the West, and you'd see how unsustainable our level of consumption is. So, I think one of the most interesting things I brought out of it myself from listening to all of you here is that we all agree that we have to look at the Western model of consumption and capitalist enterprise.

Another thing I think we all agree on, and that came from the floor as well: Away with dichotomies and away with this idea of seeing nature, culture as completely separate and mutually exclusive. However, a word of caution: Of course, there are conflicts, development versus conservation conflicts; it's not always easy to make a decision that's going to be mutually reinforcing or, as sustainable development rhetoric would have it, well, to both have your cake and eat it.

I also very much like Amita's last point about appreciation of diversity, basically both cultural, I would say, and ecological diversity. A lot of questions from the floor had to do with a definition of justice, and I'm glad to see that Veronica jumped in, and she talked about justice a bit, definition[ally], I mean there's a lot to be said about it, and I suppose all of us will be writing about it in our articles. Last point I want to make to protect my own point: I think we need an affirmative action for those who cannot speak for themselves. They will never speak for themselves. Women would; they can talk. Men-you know Black people can, homosexuals can speak for themselves. Wallabies-whatever other [for which] you see the extinction curve-will never. And the thing is not everything is needed in this interconnected axis for human survival. We can survive with monocultures; Vandana Shiva talked about monocultures of the mind, but the thing is we can also survive with agriculture monocultures. So if wallabies or bees or whoever is out of the equation, actually, ironically, nothing happens. We're not that interconnected, frankly speaking. We can do with GM foods as well, genetically modified. For that matter I would really argue - and that point is perhaps much stronger than anything that came out today-for some kind of ecological, let's say, representation, political representation, of those groups that can never speak for themselves in our human communities. Thank you.

DONALD NONINI: I think as anthropologists we all prize diversity; we prize biological diversity, cultural diversity, social diversity and many kinds of diversity. The impetus of my comments that tied together a history of two hundred to three hundred years and more of the transformation of nature and the transformation of the relationships between human beings and one another and humans beings and nature, tying that into capitalism, is - and I don't want to be misunderstood here-that deeply in these processes of the appropriation of land, fresh water, mineral resources and so forth, are processes of profound, penetrating, if you wish, simplification of precisely those things that we are talking about, celebrating as a discipline. I found myself forced into this Procrustean form that the debate seems to require, at least to my own estimation, to concentrate on some of the philosophical logical fallacies of the opponents to the motion, while sketching out a broad history as I saw it, in which this dual transformation of human beings and transformation of nature go side by side-continues concomitantly and has for several centuries in the direction of environmental simplification; hence, my example of monocropping, which has increasingly become the basis of the corporate food economy and 
so forth. I think, I want to backtrack a bit and say I appreciate very deeply the complexifying questions and richly drawn questions from the audience; they bring up many issues which some of our comments have previously addressed.

I will say one thing about the opponents representing nature. There is a joke from one Indian philosopher, some of you may know it: the devil and his companion are walking along the road together and ahead of them they spy a figure bending over and picking up something in the middle of the road, and it's glittering, and it's gorgeous. And the friend of the devil asks the devil, 'Well, who is that, that is up ahead?', and the devil replies, 'Well that's humanity,' and the friend of the devil then proceeds to ask the devil, 'Well, what is it that humanity has discovered in the road that's glittering and beautiful?', and the devil replies, 'Well, that's truth; that's what humanity has found.' The friend of the devil, then, quite surprised, steps back and says, 'Well, isn't that really bad news for you?' The devil, says, 'Oh no, no, no. Let's go ahead, catch up with her and help her organise it.' That's the problem with representing non-human nature, right? Okay.

The joke by Krishnamurti is one that, I think, pokes fun at our liberal sense of entitlement to discover new truths, simple truths, and represent them and package them-represent interest and package interest in the name of justice. And our motion, if it does anything else, if it is passed today, it will suggest that those massive simplifications which we find in liberal democracy, which we find rather difficult to understand and whose results, outcomes we find difficult to accept-we find this form of representation of nature one that we need to step back from and ask more complex and historical questions, questions that do prize diversity. But we have to do it from the point of view of the specific political and economic histories that human societies and human cultures of the modern age have participated in and the profound and deep transformations - which have required violence in simplification, violence toward human beings, simplification of our natural ecological systems, leading to what is clearly the planetary ecological crisis that we face, whose outlines I put forward to you today.

And, therefore, to conclude I'll just say, although we have to think very carefully about what justice for non-human life forms might mean before we dare take a chance of representing what that justice is, we can see the co-implications between the foundations of human life and of social reproduction with non-human life forms and the material biochemical infrastructure that is the basis of life on this planet. In that sense justice for humans necessarily needs to come before justice for the environment, but this is also justice for the environment. Thank you.

VERONICA STRANG: Thank you. I would like to sum up by just very briefly reminding you of my four key points. One, that the notion of justice is fundamentally concerned with balancing relations between those who have power and those who don't, and, as my colleague said, those who cannot speak for themselves. Two, that we're bound together in interdependent processes of production and reproduction such that the lack of justice for the non-human can have terminally disruptive effects on others and, indeed, all of us. Three, that our categories are problematic and don't reflect the realities of humanenvironmental relations, and, four, that we manifest the ideas and values that we promote.

Now, I'm very sympathetic to the concerns of my colleagues who prioritise justice for people. I think anthropologists should indeed campaign passionately for justice for humans, and over the last several decades I've spent a great deal of time working with 
Aboriginal communities on land rights and more recently in New Zealand with Maori groups to protect rights to water, but I just don't think that justice for people is enough. I don't think we can achieve justice for people without simultaneously ensuring a balance of justice for the non-human, and I think that we have to find ways to consider what that means and act accordingly, because whatever the short term needs, and we all know they're pressing, I think we would be failing in our tasks as scientists and thinkers if we don't recognise and articulate our interdependence with the non-humans and encourage societies to act accordingly. In practical terms, you know, if communities that I work with were to propose activities that would threaten the survival of other species or ecosystems, I would fear that there's a moral and intellectual imperative, and a practical imperative, to suggest alternate ways forward. And I don't actually think any of the communities I work with would have a problem with anthropologists taking that position.

I think it's very easy to be suborned to buy into discourses about what constitutes justice for people in neoliberal economies. This is so entangled with notions of development and progress that are presented in material terms and the right to have access to technologies, the right to have access to resources, to share the wealth. And the notion of developmentand I do wonder very often if the notion of sustainable development isn't, in fact, an oxymoron-seems inevitably tied to the adoption of growth-based economic practices in which the costs are invariably externalised to other species and things. And, as my account of the species extinctions has illustrated, this has led to a very sharp loss of justice for the environment. I would put it to you that it will also lead, is leading, not to a better distribution of wealth or human rights, but to greater conflict over land and resources and so, in the longer term, to less justice for people.

So, to date, the prioritisation of immediate human needs and the adherence to the view of humankind as somehow separate from nature or the environment has brought us to the point where we're actually in danger of bringing down the ecosystems on which we rely. In that, in the larger scheme of things, [I] suggest that asking more complex historical questions-while it's a very valid point of view involving prioritising the justice of people-until we've sorted out those complex questions may constitute fiddling while Rome burns. So, for me, this debate raises a question as to what we as anthropologists want to promote as a vision for humankind, not just now, but in the longer term.

I think we can all agree that the non-human and human relations are social-political relations. The bioethical position that we adopt reflects the balance of power, the balance of justice in these, and when we resituate ourselves within those relationships, it actually seems rather repellant to promote a way forward, to suggest that human needs must always come first. I would rather see anthropology present an integrated conceptual view and a moral lead that upholds the capacity for collaborative rather than competitive relationships, not only between human groups but between human and other kinds, and that to me means giving simultaneous, not secondary, consideration to the needs of non-human species and ecosystems. So I would argue that rather than prioritising justice for people, we should instead promote justice for all, and I ask you to vote against the motion. Thank you.

In a vote by the audience, the motion was defeated. 


\section{Notes}

1. See http://www.socialsciences.manchester.ac.uk/subjects/social-anthropology/our-research/group -debates-in-anthropological-theory/ and http://coa.sagepub.com/content/33/3/300.abstract.

2. In theoretical terms, both ecological Marxism (e.g., O'Connor 1998) and most variants of political ecology (e.g. Biersack 2006) are in agreement regarding these propositions.

\section{References}

Benjaminsen, T. A., R. Rohde, Espen P. Sjaastad, P. Wisborg, and T. Lebert. 2006. "Land Reform, Range Ecology, and Carrying Capacities in Namaqualand, South Africa." Annals of the Association of American Geographers 96 (3): 524-540.

Biersack, Aletta. 2006. "Introduction." In Reimagining Political Ecology, edited by A. Biersack and J. Greenberg, 3-40. Durham, NC: Duke University Press.

Brockington, D., R. Duffy, and J. Igoe. 2008. Nature Unbound. Conservation, Capitalism and the Future of Protected Areas. London: Earthscan.

Crist, E. 2012. "Abundant Earth and Population." In Life on the Brink: Environmentalists Confront Overpopulation, edited by P. Cafaro and E. Crist, 141-153. Athens, GA: University of Georgia Press.

Desmond, J. 2013. "Requiem for Roadkill: Death and Denial on America's Roads." In Environmental Anthropology: Future Trends, edited by Helen Kopnina and Eleanor Shoreman-Ouimet, 46-58. London: Routledge.

Drayton, Richard. 2000. Nature's Government: Science, Imperial Britain, and the 'Improvement' of the World. New Haven, CT: Yale University Press.

Elwin, Verrier. [1939] 2007. The Baiga. Delhi: Gyan Publishing House.

Guha, Ramachandra. 1989. "Radical American Environmentalism and Wilderness Preservation: A Third World Critique." Environmental Ethics 11 (1): 71-83.

Horkheimer, Max, and Theodor W. Adorno. 1972. Dialectic of Enlightenment. New York: Herder and Herder.

Igoe, J., and D. Brockington. 2007. "Neoliberal Conservation: A Brief Introduction." Conservation and Society 5 (4): 432-449.

Kottak, Conrad P. 1999. “The New Ecological Anthropology.” American Anthropologist 101 (1): 23-35.

Leopold, A. [1949] 1987. A Sand County Almanac and Sketches Here and There. New York: Oxford University Press.

Marx, K., and F. Engels. 1973. The German Ideology: Part One. Edited by C. J. Arthur. New York: International Publishers.

Naess, A. 1973. "The Shallow and the Deep, Long-range Ecology Movement: A summary." Inquiry 16: 95-100.

Nas, P. J. M., J. Zhang, and P. Ji. 2009. Anthropology Now: Essays by the Scientific Commissions of the International Union of Anthropological and Ethnological Sciences (IUAES) and History of the International Union of Anthropological and Ethnological Sciences (IUAES). Beijing: Intellectual Property Publishing House.

Neumann, Roderick P. 2001. "Disciplining Peasants in Tanzania: From State Violence to State Surveillance in Wildlife Conservation." In Violent Environments, edited by Nancy Peluso and Michael Watts, 305-327. Ithaca: Cornell University Press.

Noske, B. 1989. Humans and Other Animals. London: Pluto Press.

O’Connor, James. 1998. Natural Causes: Essays in Ecological Marxism. New York: Guilford Press. Polanyi, Karl. 1944. The Great Transformation: The Political and Economic Origins of our Time. Boston, MA: Beacon Press.

Pountney, J. 2012. “Book Review: Kalland.” Unveiling the Whale. Durham Anthropology Journal 18 (1): 215-217.

Shiva, V. 2012. Everything I Need to Know I Learned in the Forest. http://www.yesmagazine.org/issues/ what-would-nature-do/vandana-shiva-everything-i-need-to-know-i-learned-in-the-forest. 
Strang, V. 2016. "Justice for All. Inconvenient Truths and Reconciliation in Human-non-human Relations." In Routledge International Handbook of Environmental Anthropology, edited by H. Kopnina and E. Shoreman-Ouimet. New York: Routledge.

Thompson, E. P. 1975. Whigs and Hunters: The Origin of the Black Act. New York: Pantheon Books. West, P., J. Igoe, and D. Brockington. 2006. "Parks and People: The Social Impact of Protected Areas." Annual Review of Anthropology 35: 251-277.

Williams, R. 1980. Problems in Materialism and Culture: Selected Essays. London: Verso. 